\title{
Species limits within Grey-headed Quail-dove Geotrygon caniceps and implications for the conservation of a globally threatened species
}

\author{
ORLANDO H. GARRIDO, GUY M. KIRWAN and DAVID R. CAPPER
}

\begin{abstract}
Summary
Grey-headed Quail-dove Geotrygon caniceps has traditionally been considered a polytypic species endemic to Cuba and the Dominican Republic and treated as globally threatened within the most recent Red Data Book (BirdLife International 2000). Chapman (1917) described Geotrygon leucometopius of Hispaniola as specifically distinct from G. caniceps of Cuba based on 10 specimens, taken by Rollo Beck in the Dominican Republic. Subsequently, Bond (1936, 1956) merged leucometopius within caniceps, an arrangement that has persisted, unchallenged in the technical literature, until the present. Through examination of 76 specimens, extensive field experience of Cuban birds, and less exhaustive fieldwork in the Dominican Republic, we re-evaluate the taxonomic status of the Hispaniolan population, identifying consistent differences in coloration, tail length and characteristics of the second to fifth primaries between it and the Cuban population. Based on these differences, we suggest that caniceps (endemic to Cuba) and leucometopius (restricted to the Dominican Republic) be henceforth resurrected to species status. We were unable to undertake a complete analysis of the vocalizations of the two forms, due to the lack of definite recordings from Hispaniola, but present sonograms and notes concerning Cuban birds. Further work, including molecular analyses, would be clearly desirable to test our hypothesis. Both forms are undoubtedly declining due to habitat destruction and hunting, and both certainly qualify as Vulnerable under current IUCN criteria. Indeed, leucometopius may even qualify as Endangered under the range criterion. Its status requires particularly careful monitoring, while new information, published since the BirdLife International (2000) review of globally threatened birds, suggests that the range even of nominate caniceps is considerably smaller than previously considered.
\end{abstract}

\section{Resumen}

El Camao (Perdiz Coquito Blanco) Geotrygon caniceps es un especie polytipica endémica de Cuba y la la República Dominicana, y señalade como amenazada globalmente en el Libro Rojo más reciente (BirdLife International 2000). En base a 10 especímenes, colectados por Rollo Beck en la República Dominicana, Chapman (1917) describió Geotrygon leucometopius como una especie diferente de G. caniceps de Cuba. Posteriormente, Bond (1936, 1956) juntó leucometopius y caniceps, y ese arreglo permaneció sin ser contradicho en la literatura técnica, hasta el presente. A través del examen de 76 especímenes, extensa experiencia de campo con las aves cubanas (y trabajo de campo menos exhaustivo en la 
República Dominicana), reevaluamos el estatus taxonómico de la población de Hispaniola, identificando diferencias consitentes en coloración, longitud del cola y características del segundo a cinco remeras primaria entre ésta y la población cubana. En base a estas diferencias, sugerimos que caniceps (endémica de Cuba) y leucometopius (restringida a la República Dominicana) sean de aquí en más tratadas a nivel específico. No nos fue posible llevar a cabo un análisis completo de las vocalizaciones de ambas formas, debido a la falta de grabaciones realizadas con certeza en Hispaniola, pero presentamos sonogramas y información de la población cubana. Sería deseable probar nuestras teorías con más información, incluyendo análisis moleculares. Ambas formas se encuentran sin duda en receso dada la destrucción del hábitat y caza, y califican como Vulnerales en base a los criterios actuales de la UICN. De hecho, leucometopius podría inclusive ser clasificada como En peligro bajo el criterio de distribución. Su estatus requiere monitoreo cuidadoso, mientras que nueva información publicada desde la revisión de aves globalmente amenazadas por BirdLife International (2000) sugiere que la distribución de inclusive la forma nominal caniceps es considerablemente menor de lo que se consideraba previamente.

\section{Introduction}

Grey-headed Quail-Dove Geotrygon caniceps is a globally threatened species, restricted to Cuba and the Dominican Republic, in the Greater Antilles (BirdLife International 2000). In Cuba it is rare, with most records from the west and centre of the main island (although this partially reflects observer activity), while, in the Dominican Republic, it persists on the Cordillera Central, Sierra de Baoruco and Sierra de Neiba (BirdLife International 2000, Keith et al. in press). Reports exist from the 1920 s of a rare grey quail-dove that inhabited montane scrub near the summit of Morne La Selle, in extreme south-east Haiti (Bond 1928) and probably also occurred in Massif du Nord, in central-east Haiti (Keith et al. in press), but intensive habitat destruction has almost certainly extirpated any population that may have existed in that country (Stattersfield et al. 1998). It remains very locally not uncommon on the Sierra de Baoruco (GMK pers. obs.), but there are no recent reports from the Sierra de Neiba (BirdLife International 2000) and its status in the Cordillera Central is poorly known. Previous publications on Red Data birds treated it as Near-threatened (e.g. Collar et al. 1992, 1994), but evidence of a continued and rapid population decline, owing to habitat destruction and hunting, has prompted its reclassification as Vulnerable (BirdLife International 2000). Nonetheless, as long ago as the first quarter of the twentieth century, Barbour (1923) noted a decrease in Cuba, and Keith et al. (in press) considered Hispaniolan populations to have been declining since 1930.

Columba caniceps was originally described from Cuba (Gundlach 1857) but, in 1917, Rollo Beck discovered a similar form in Hispaniola, which Chapman (1917) described as Geotrygon leucometopius and considered closely allied to Cuban Geotrygon caniceps. They were maintained as separate species, e.g. by Wetmore and Swales (1931), for nearly two decades, until Bond $(1936,1956)$ elected to treat caniceps as polytypic, merging leucometopius within caniceps. Subsequent treatments, including that of the latest AOU Check-list (1998) and Raffaele et al. (1998), have followed Bond's systematic arrangement. 
No revision of the taxonomy of G. caniceps, considering behaviour, habitat or vocalizations, has since been attempted. With the exception of Wetmore and Swales (1931), all subsequent authors (including most recently Gibbs et al. 2001) have apparently dismissed, or ignored, the important character that led Chapman (1917) to describe the Hispaniolan form as distinct: the notch in the second primary, situated at 51-57 $\mathrm{mm}$ in 1o leucometopius measured by Chapman, versus 64-69 $\mathrm{mm}$ in five caniceps (but see Morphometric comparisons below). Chapman (1917) observed that the 'color differences are sufficiently pronounced to be more than differences of degree, while the unusual character supplied by the emargination of the second to fifth primaries (from without) is also evidence of prolonged segregation and specific distinctness'. ${ }^{1}$

Quail-doves as a group have attracted comparatively little recent taxonomic attention, with the exception of the Tuxtla or Veracruz Quail-dove Geotrygon carrikeri, which was afforded specific status from the morphologically similar Purplish-backed Quail-dove G. lawrencii, based on the separate application of both the Phylogenetic (Peterson 1993) and Biological Species Concepts (Howell 1998), acquiring a certain degree of resultant notoriety (Howell 1999, Peterson 1999). The systematic question posed by these two Middle American quail-doves appears analogous to that of Grey-headed Quail-dove, albeit within an insular, rather than continental, context: two similarly plumaged (see plate 13 in Baptista et al. 1997) and closely related, but certainly far from identical, taxa that exhibit some additional differences in habitat preferences, and which are pursuing separate evolutionary trajectories. In the case of caniceps and leucometopius, we can add structural features to the list of characters that differentiate the two forms. It is notable that Wetmore $(1920,1922)$ described from a number of fossil deposits a quail-dove of the same type (Oreopeleia [= Geotrygon] larva) on neighbouring Puerto Rico. This apparently close ally of the caniceps group was subsequently discovered in kitchen midden deposits, proving that it survived beyond human colonization of the island (Wetmore 1927), but it has attracted no subsequent attention in the literature.

We also seek to analyse, using the well-defined criteria employed by IUCN and BirdLife International for assessing extinction risk, the relative conservation status of the two forms.

\section{Material and methods}

OHG examined 64 adult specimens of Geotrygon caniceps, 26 from Hispaniola and 38 from Cuba. In addition, GMK independently examined specimens of caniceps from Cuba (in Museo Nacional de Historia Natural de Cuba, La Habana) and from both Cuba and Hispaniola (in Natural History Museum, Tring [NHM]). Chris Milensky measured three of five specimens held in the National Museum of Natural History, Washington, DC, the two other specimens being in too great

\footnotetext{
${ }^{1}$ Note that here, in common with modern usage (see Svensson 1992), we use the term notch, rather than emargination, to describe this distinctive feature. A reading of Chapman's type description clearly indicates that he is referring to the notch, not emargination (according to modern definitions) and that his data are comparable with ours in this respect.
} 
a state of disrepair to permit the acquisition of mensural data. These additional morphometric data were not included within the dataset prepared by OHG, in order to eliminate any discrepancies in measuring techniques, but anyway were comparable with the measurements obtained by OHG. A full list of institutions at which specimens were examined and details of the locality and sex of each are presented in Appendix 1. Measurements taken were flattened wing and tail length (using a wing rule to the nearest $0.5 \mathrm{~mm}$ ), and tarsus and culmen length (using digital calipers to the nearest $0.1 \mathrm{~mm}$ ). Culmen length was taken from the anterior end of the nares to the tip. The position of the notch in the primaries was measured using a transparent ruler to the nearest $0.5 \mathrm{~mm}$. Sex-related and taxa-based differences betweeen the four morphometric variables were tested for using two-way Analysis of Variance. Thereafter, post-hoc analyses were performed using Scheffe tests. Sonograms of the vocalizations were analysed using a Macintosh computer and Canary version 1.2.1 software (Bioacoustics Research Program, Cornell Laboratory of Ornithology, Ithaca, New York), and prepared for publication by Richard Ranft of the British Library National Sound Archive, London, using Avisoft.

\section{Results}

Morphometric comparisons

We analysed 64 specimens: 26 from Hispaniola and 38 from Cuba. Morphometric data for each specimen are presented in Appendix 3.

Males had significantly longer wings $\left(\mathrm{F}_{1,57}=8.7, P<0.01\right)$ and tarsi $\left(\mathrm{F}_{1,58}=\right.$ 38.4, $P<$ 0.01) than females for both taxa. Between taxa, significant differences were only found in tail length $\left(F_{1,54}=57.8, P<\right.$ 0.01) (Figure 1$)$. There were no significant interactions between the forms and sexes (see Figure 1). Our measurements of the diagnostic character (the notch on the first primary) discovered by Chapman (1917) in his description of leucometopius, revealed that those from Cuba averaged $58.5 \pm 2.7 \mathrm{~mm}$, whereas the mean for Hispaniolan individuals was $53.7 \pm 3.1 \mathrm{~mm}$. The present analysis therefore confirms the significance of this character within interpopulation differentiation. We are unable to explain the reason for the notable disparity between Chapman's and our figures for this critical character, but note the considerable difference in respective sample sizes.

\section{Morphological features}

In his description of G. leucometopius, Chapman (1917) summarized the manner in which the new form differed in colour and pattern from G. caniceps: 'Similar to Oreopeleia caniceps, but forehead white rather than gray, crown, nape, and sides of head slate instead of gull-gray; back slightly darker, more bluish; wing-quills darker, with less russet or cinnamon; emargination of primaries nearer the tip; sides of breast more extensively metallic purple; ventral region more russet'. Chapman's description may be added to, based upon our exam- 
Species limits within Grey-headed Quail-dove Geotrygon caniceps

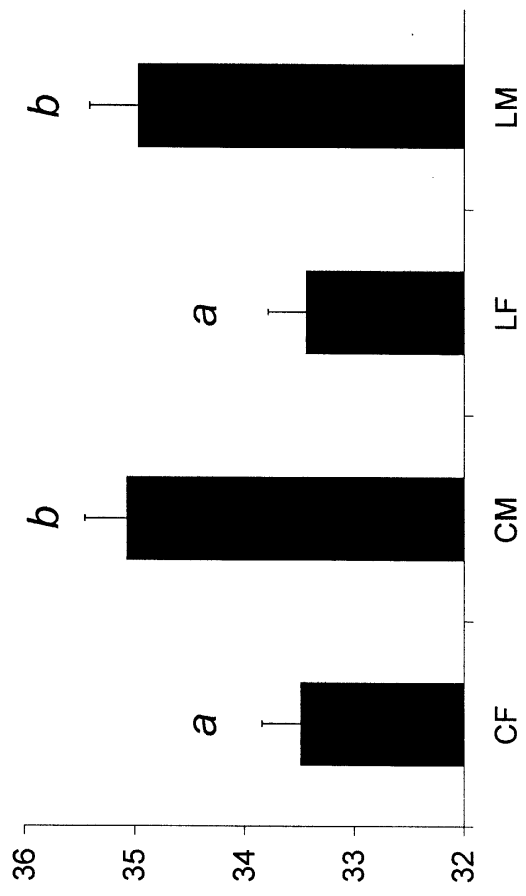

(um) $\exists S \mp$ पlбuə| snsıe $\perp$

$\Sigma$

แ

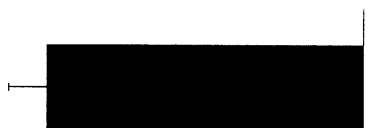

$\sum$

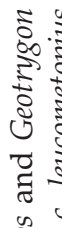

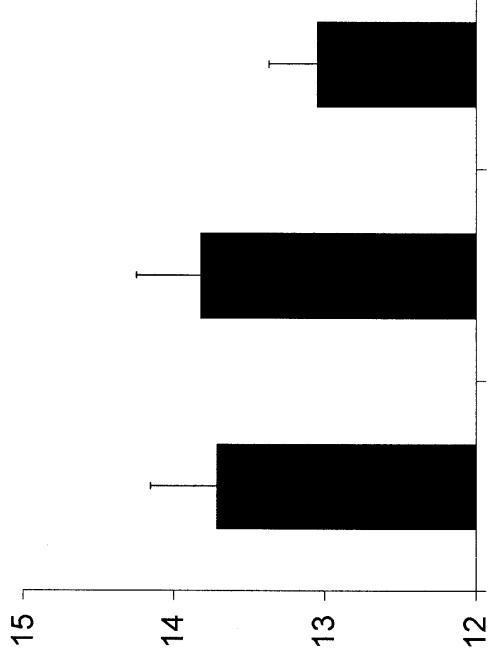

$\amalg$

$\frac{8}{2} \frac{1}{3}$

3
0
0
0
0
0
0
0
0
0
0
0
0
0
0
0
0

ن

$\sum_{0 \rightarrow 1}^{\infty}$

$\sum_{0}$

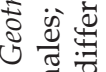

(

요요

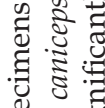

u

का 15

प艹

क⿱艹

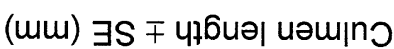

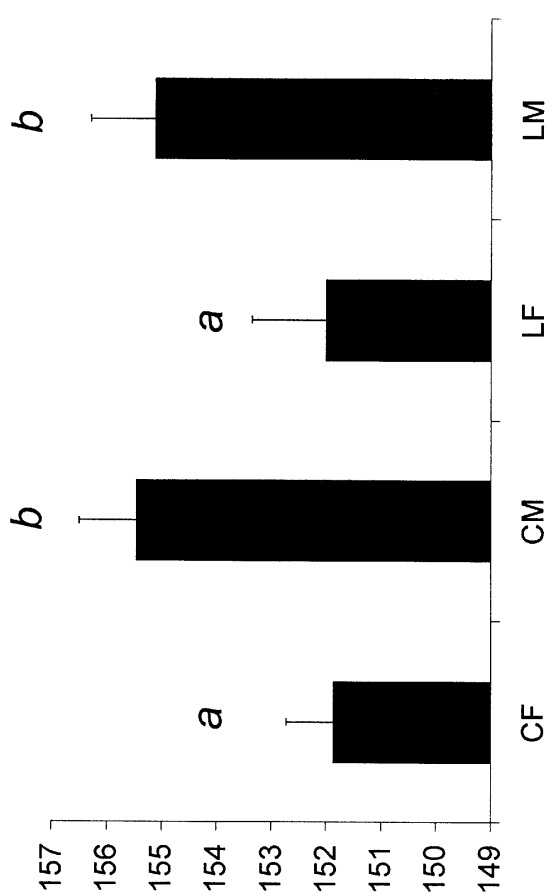

$\sum$

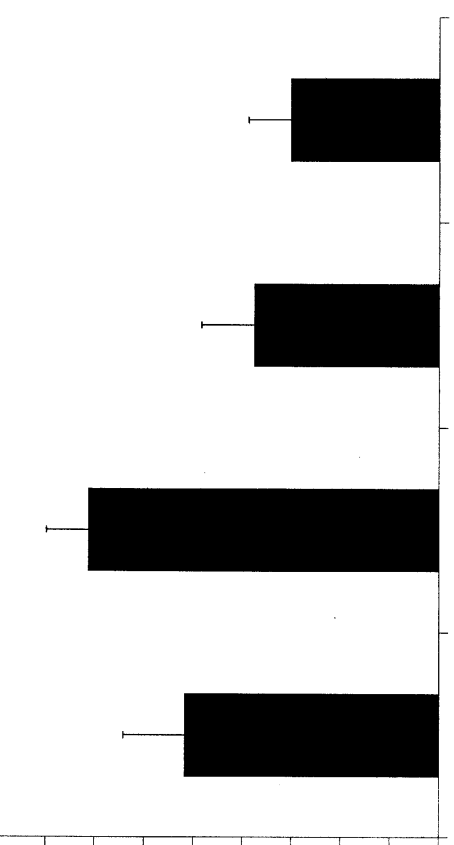

สั ชั

(mu) $\exists S \mp$ чlбиә bu!M

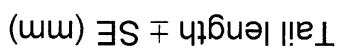

$\sum$

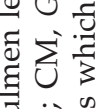

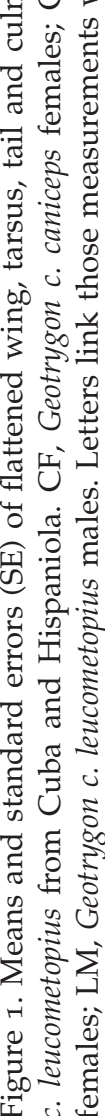


ination of specimens (Appendix 1) and extensive field observations of both taxa, particularly caniceps. Perhaps most significant is the head pattern: leucometopius has a conspicuous and striking white forehead, which is restricted to the fore part of the crown, in front of the eye, and contrasts markedly with the rest of the head, but in caniceps the forehead patch is much more diffuse, less markedly clean and hence less noticeable, and slightly more extensive; this feature is obvious consistently in the field. The rest of the head, including the pileum and nape, is a darker and deeper grey in leucometopius; in some caniceps that we have examined the entire crown and nape may be only marginally darker than the forehead. In some Cuban specimens the violet gloss to the mantle is less extensive than in leucometopius (though at least one of these was an individual that had been kept in captivity for some time and was thought to have undergone some plumage changes as a result), but in most caniceps it is similar to those from Hispaniola. Most Cuban specimens have a greyish-brown suffusion to the neck-sides, but those from Hispaniola consistently exhibit a strong reddish-purple or violet suffusion to this feather tract, which, in some specimens and individuals that we have observed in the field, extends onto the breast and almost forms a complete band across the underparts. Only a few caniceps display any purplish on the neck-sides, and this is always highly restricted in extent and duller than in Hispaniolan birds.

In specimens, the blue colour of the back, uppertail-coverts and rump is relatively similar, in extent and intensity, in both Cuban and Hispaniolan forms (but see below for the striking dissimilarity in live birds). Ventrally, the two forms appear quite similar, but leucometopius is darker on the breast and lower throat. The cinnamon colour of the rear flanks and undertail-coverts is typically darker in leucometopius, but this feature is not consistent in all series (e.g. those at NHM are not noticeably different in this respect from caniceps specimens held at the same institution). Some leucometopius specimens, including all those held at NHM, have paler (whitish-tipped) throat feathers, a feature that we have never observed in caniceps. The primary tips are darker and more blackish in leucometopius, contrasting more noticeably with the cinnamon shafts to these feathers. These differences are constant in comparisons of specimens of the same age or taken at the same season. In general, the metallic gloss of the upperparts feathering in leucometopius is significantly more vivid. Most leucometopius that we have observed in the field in strong light appear to have strikingly deep blue upperparts and head, with the exception of the gleaming white forecrown, and brilliant reddish-purple necksides; this level of contrast and intensity of coloration are features that we have never observed in the great many caniceps that we have studied in Cuba (but note that these differences are not apparent in specimens). No significant differences in bare-parts coloration were observed between the two taxa; the bills of both frequently become paler distally, many adults having yellowish tips. Young of both taxa are browner than adults and lack the reddish/ bluish-purple sheen to the mantle and neck-sides. We found that intra-island populations are very similar in size and coloration, with only slight individual variation, and are thus unable to discern any intra-island subspecific geographical differences. 


\section{Discussion}

\section{Habitat and natural history}

Few data are available concerning the habitat and natural history of these secretive doves. The summary of published and unpublished information presented here will undoubtedly be subject to future refinement by fieldworkers on the two islands. In Cuba, practically the only available information is that of Rodríguez and Sánchez (1993) who conducted field studies in the Ciénaga de Zapata, as well as of captive birds. Gundlach $(1876,1893)$ also presented observations of wild G. caniceps, as did Mitchell and Wells (1997). Habitat used by G. caniceps (sensu stricto) varies considerably among regions. In the Ciénaga de Zapata, caniceps occurs in rather dry woods, though with permanent small pools (OHG and GMK pers. obs.). During the wet season these areas become semi-inundated. Mitchell and Wells (1997) also considered caniceps to favour this habitat, but it also occurs in the wettest forests immediately bordering the swamp, e.g. at Peralta (Wells and Mitchell 1995, OHG and GMK pers. obs.), which are at least partially inundated almost year-round. Only caniceps and Ruddy Quail-dove Geotrygon montana appear to occur in these areas. Within the adjacent zone of deciduous woods on limestone, Blue-headed Quail-dove Starnoenas cyanocephala and Ruddy Quail-dove are the commoner species, but in some areas within this habitat type all three species occur sympatrically. The situation is further complicated by our observations in other seasonally wet forests, e.g. at Pálpite, which demonstrate that these three species, and Key West Quail-dove G. chrysia, can occur sympatrically, although Starnoenas is usually the rarest of the four and clearly favours drier, limestone-based forest. All four may also congregate at water holes, e.g. they were all observed interacting at a sinkhole at Bermejas during the 1995 dry season (Wells and Mitchell 1995). In the Sierra del Rosario, Pinar del Río Province, G. c. caniceps occurs in mid-elevation humid forest, a habitat shared with G. montana, G. chrysia and S. cyanocephala, though Wells and Mitchell (1995) found caniceps and montana to be the commoner of the four during their surveys. G. caniceps is also regularly observed, at 1,200 m, in Lomo del Caldero (OHG and GMK pers. obs., A. Kirkconnell pers. comm.). Though OHG did not record caniceps at Pico Turquino, east Cuba, Rollo Beck secured a small series there in the 1920s. Humid forests occur in several zones of this peak. At lower elevations (below $700 \mathrm{~m}$ ) of Pico Turquino, OHG heard S. cyanocephala, but did not observe any quail-dove species above $600 \mathrm{~m}$. However, in late 2000, A. Kirkconnell and Y. Aubry rediscovered caniceps in the Sierra Maestra, recording it at $c .1,850 \mathrm{~m}$ on Pico Cuba. The level of ornithological fieldwork in this region of the country is still very low.

Habitats used by this dove in Hispaniola are better documented than those in Cuba (e.g. Chapman 1917, Wetmore and Swales 1931, Bond 1936, Stockton de Dod 1978, 1981, Pérez Rivera and Ruiz-Lebrón 1997, Raffaele et al. 1998). Previously, the Dominican Republic population was considered to be exclusively an inhabitant of wet montane forests to 1,800 m (Baptista et al. 1997, though we are unable to trace altitudinal reports from above 1,685 m; Kirwan et al. 1999, Keith et al. in press), whereas the Cuban form was thought to be restricted to lowland habitats. Recent research has revealed that those in the Dominican Republic are also found at low elevations (Stockton de Dod 1978, 1981), being known from 
two localities at sea level (Baptista et al. 1997; though these possess quite different vegetation from known sites in $\mathrm{Cuba}$, being much drier xerophytic areas, characterized by tall columnar cacti, emergent palms and 1 to $3 \mathrm{~m}$-tall scrub), and that the Cuban form also occurs in mid-elevation forests (Garrido and García Montaña 1975, Garrido and Kirkconnell 2000, Raffaele et al. 1998; OHG and GMK pers. obs.). OHG and GMK have observed leucometopius on a number of occasions in the Dominican Republic, at c. 1,300-1600 m, in the Cordillera Central and Sierra de Baoruco, in April 1998, August 1999 and March 2000. In our experience, leucometopius does indeed prefer wet montane forest with dense undergrowth, though it has apparently been recorded near sea level in abandoned coffee cultivations (A. Stockon de Dod in litt. 1986 to BirdLife International). What is clear is that despite greater overlap in their habitat preferences than was previously considered to exist, the two occupy different ecological niches, with leucometopius being found principally in montane regions and caniceps in drier woodlands at lower altitudes.

Regarding courtship and clutch size, Pérez-Rivera and Ruiz-Lebrón (1997) recapitulated the available information published by other authors, as well as their own observations on captive birds in Santo Domingo. They made a detailed explanation of the courtship behaviour employed by males in front of females, both from the ground and from the nest. Comparable observations have not been described yet from Cuban birds.

The breeding season is apparently January-August, but in Cuba at least, calling occurs throughout the year, though vocal activity is strongly diminished during the wet season (May-September). Indeed, Gundlach (1871) found a nest with two eggs in Cuba in August and a female (in American Museum of Natural History, New York [AMNH]) taken on Pico Turquino in early August was ready to lay, suggesting that the season is possibly year-round in Cuba. We have personally observed only four nests, all in Ciénaga de Zapata (La Cocodrila, Santo Tomás, Peralta and Bermejas), Cuba. All were similar, typically flimsy Columbidae structures, comprising a loose assemblage of grasses and twigs. Three were placed c. $1.5 \mathrm{~m}$ above the ground on a forked twig near the main branch of a bush. The fourth was within a central depression of a broken palm, surrounded and masked by tall grass. A. Kirkconnell (pers. comm.) has also found nests situated in a depression within the main trunk of a tree. Nest situation is recorded as being in a bush or vine tangle, 1-3 $\mathrm{m}$ above ground, by Raffaele et al. (1998). Barbour (1923) records that three ochraceous-white eggs constitutes a typical clutch, but our observations and those of Raffaele et al. (1998), suggest that 1 or 2 whitish-beige eggs are more usual.

\section{Vocalizations}

Our efforts to compare the vocalizations of these doves on both islands were stymied due to a lack of recordings from Hispaniola. Richard Ranft (in litt. December 2000) stated that recordings presented by Reynard (1981) produce identical sonograms to those on Hardy et al. (1989) (where stated to have been made in Cuba), and Reynard and Garrido (1988). It is certain that all of Reynard's published recordings are from Cuba and cannot be used for inter-taxa comparison. Nonetheless, we present sonograms (Figure $2 \mathrm{a}-\mathrm{c}$ ) of caniceps, to illustrate 
(a)

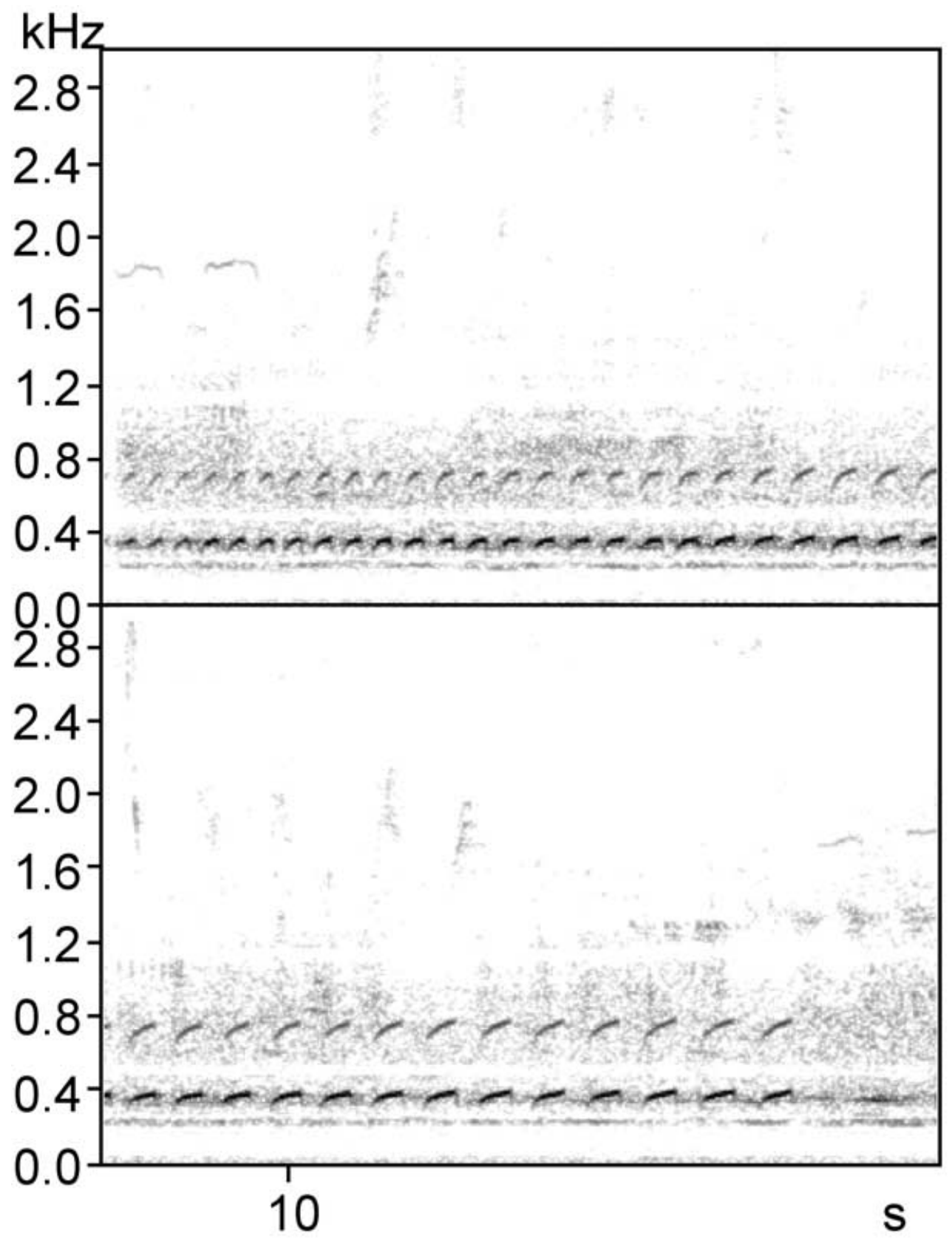

Figure 2a-c Sonograms of vocalizations of Geotrygon c. caniceps. All were prepared by Richard Ranft using the Avisoft programme. a Fast song of Geotrygon c. caniceps, recorded by George B. Reynard, 'Playa Larga', Cuba, 25 April 1978. b Slow song of Geotrygon c. caniceps, recorded by George B. Reynard, 'Playa Larga', Cuba, 25 April 1978. c Fast song of Geotrygon c. caniceps, changing to slow song, recorded by Guy M. Kirwan, Pálpite, Cuba, 26 July 2000. 
(b)

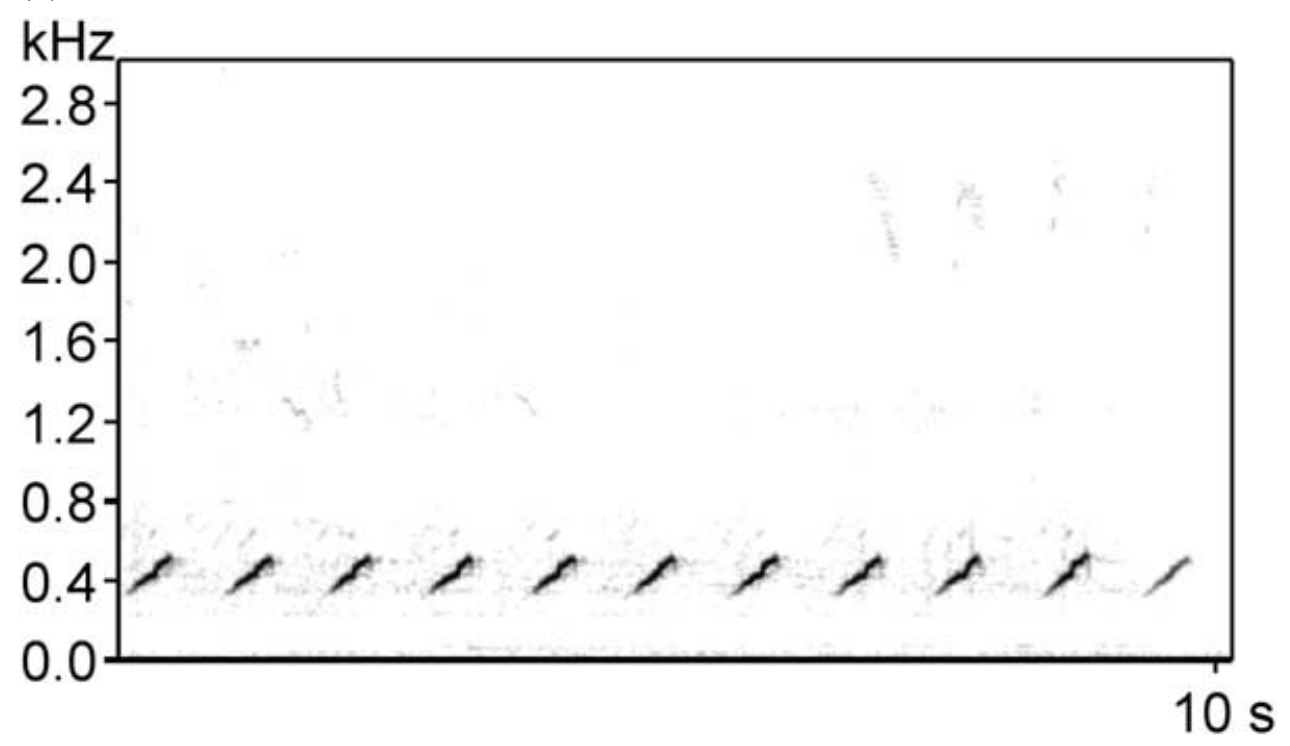

(c)

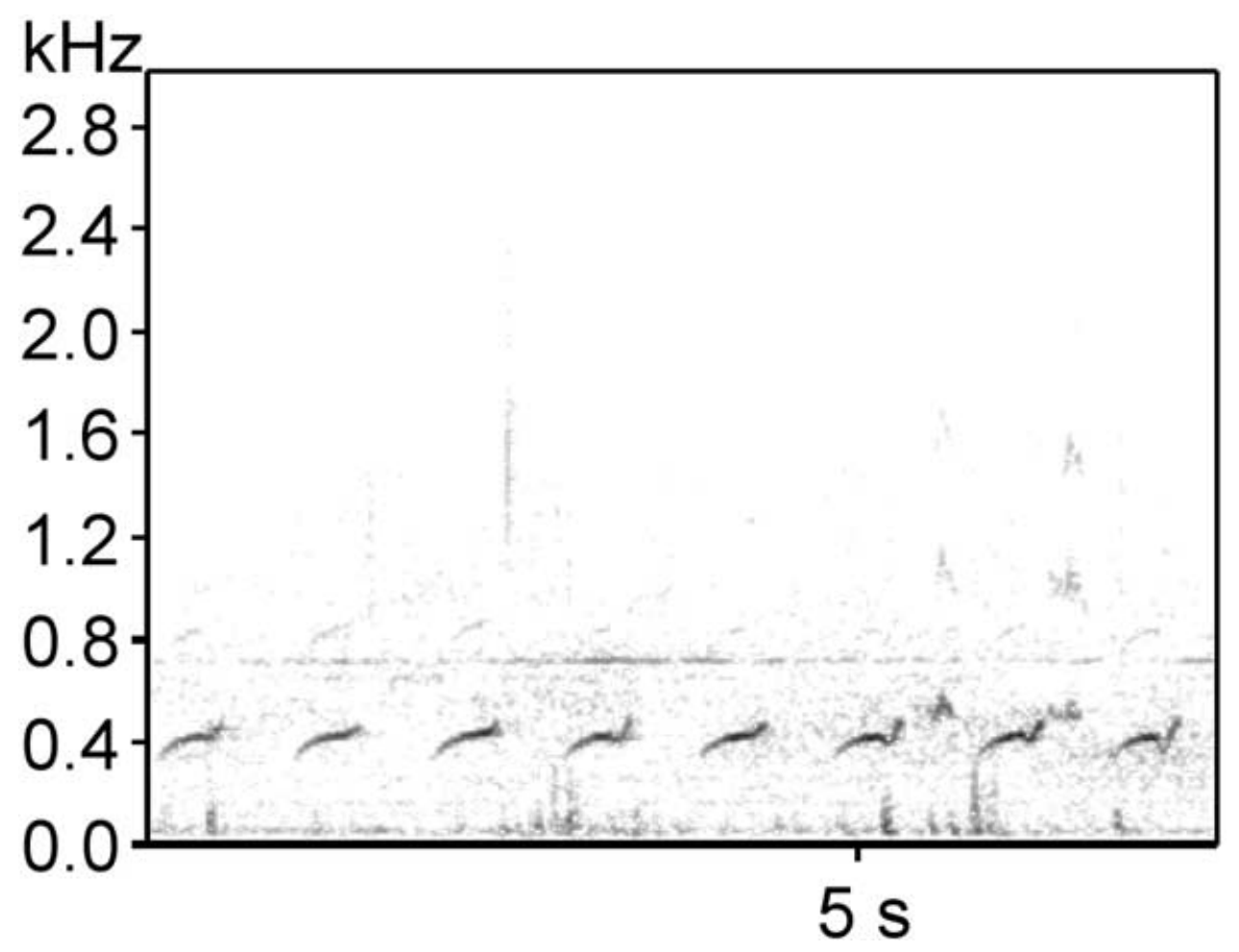

Figure 2. Continued. 

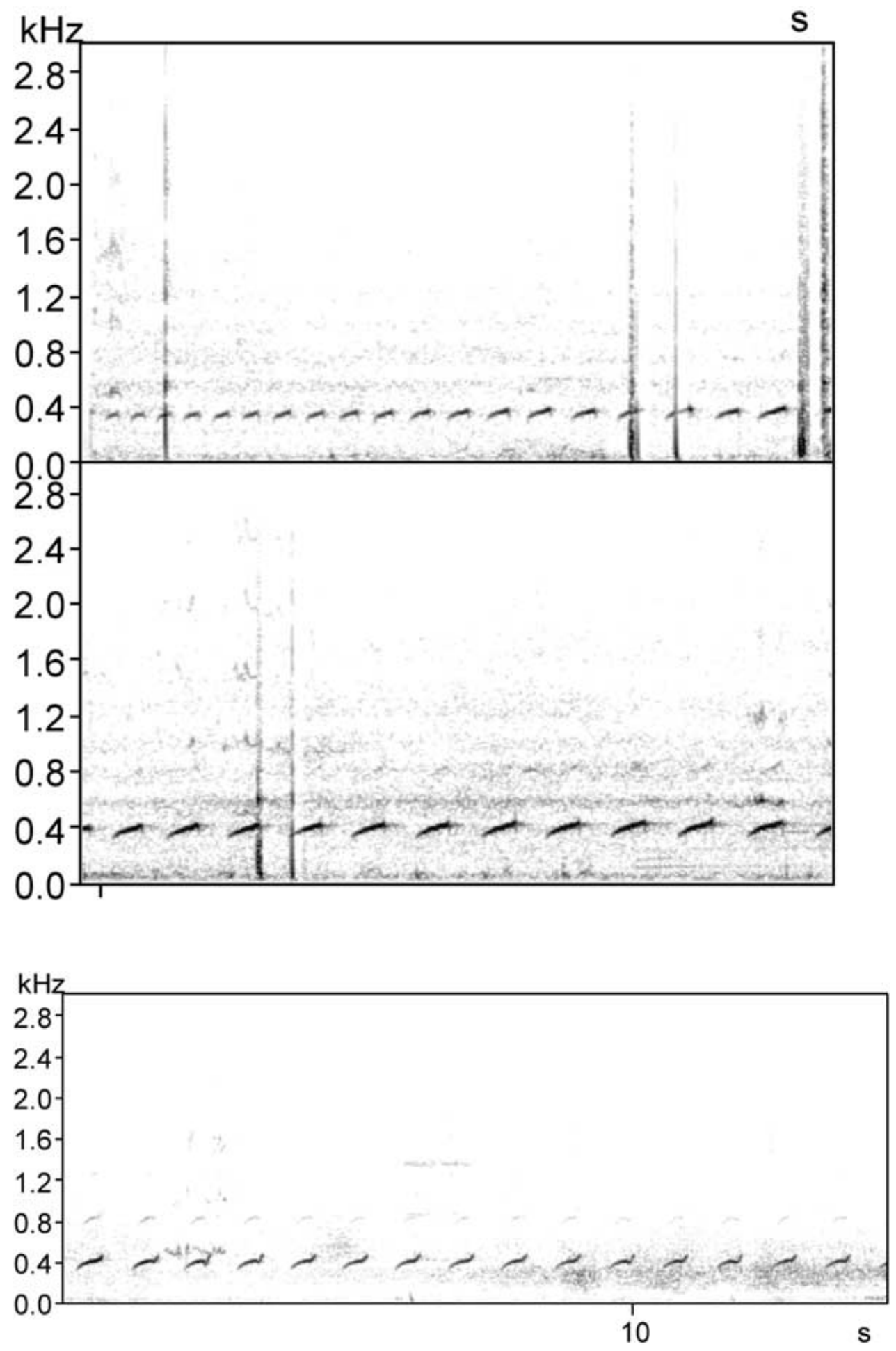

Figure 2. Continued. 
the two principal vocalization types, the fast and slow songs, which may be given separately or during the same 'song' (see Figure 2c), and to provide comparative data for future workers to build upon. We hope that future researchers will be able to acquire recordings of leucometopius and compare these with caniceps, and provide further data to support our theory that two basal taxa ('species') are involved, much as Howell (1998) added to Peterson's (1993) work on G. carrikeri. GMK has twice heard the fast song in the Dominican Republic and considers it very similar to the corresponding vocalization in Cuba.

\section{Conservation status of the two forms}

Following Bond (1936, 1956), AOU (1998) and Raffaele et al. (1998), BirdLife International (2000) treated these two taxa as one species. Using the Red List criteria established by the IUCN in 1994, G. caniceps was listed as globally threatened in the category Vulnerable for two reasons. First, high rates of habitat loss and hunting were suggestive of rapid and ongoing population declines exceeding $20 \%$ in 10 years or three generations (criteria A1a,b,e; A2c,d). Second, these rates of decline were combined with a total population estimated at below 10,000 individuals (criteria $\mathrm{C}_{1}$ ).

Treatment of the Cuban and Hispaniolan forms as different species requires that their conservation status be assessed separately. Three criteria set out in IUCN (1994) are applicable. First, criterion A, relating to rapid population declines. The BirdLife International (2000) assessment was based on both forms undergoing population declines of above $20 \%$ in 10 years. There is no reason to suppose that this has changed and therefore both qualify as Vulnerable under A1a,c,d; A2c,d. Second, criterion B, relating to small and declining ranges. BirdLife International (2000) estimated the range size of $G$. caniceps to be $c .28,000 \mathrm{~km}^{2}$. This was more precisely mapped by Thomas Stuart and DRC as $28,699 \mathrm{~km}^{2}$, consisting of c. $23,330 \mathrm{~km}^{2}$ on Cuba and c. 5,369 $\mathrm{km}^{2}$ in the Dominican Republic. G. c. leucometopius has a range of less than $20,000 \mathrm{~km}^{2}$ and is known from three main areas. It has apparently disappeared from one of these, the Sierra de Neiba, and is currently known from fewer than 11 locations in the Cordillera Central and the Sierra de Baoruco. Continuing habitat loss in these areas indicates that there is an ongoing contraction in extent of occurrence, area of occupancy, reduction in habitat quality, number of locations and numbers of mature individuals. Therefore, this form qualifies as Vulnerable under $\mathrm{B} 1+2 \mathrm{a}, \mathrm{b}, \mathrm{c}, \mathrm{d}, \mathrm{e}$. However, a more detailed knowledge of its range may prove that the range is below the 5,000 $\mathrm{km}^{2}$ threshold demanded for qualification as Endangered. By contrast, the range of G. c. caniceps remains above the $20,000 \mathrm{~km}^{2}$ threshold for Vulnerable status. However, Garrido and Kirkconnell (2000) mapped this form with a refined range, which has been digitized at $11,741 \mathrm{~km}^{2}$ (Thomas Stuart in litt. 2001). The form is currently known from fewer than 11 locations which, combined with range and population declines, qualifies it as Vulnerable under $\mathrm{B}_{1}+$ $2 \mathrm{a}, \mathrm{b}, \mathrm{c}, \mathrm{d}, \mathrm{e}$. Third, criterion $\mathrm{C}$, relating to small and declining populations. It seems unlikely that either form has a population below 2,500 individuals. However, following the BirdLife International (2000) assessment, both must have a population below 10,000 individuals. Given the rates of decline mentioned above, both forms qualify as Vulnerable under $C_{1}$. With the exception of the population in 
the Ciénaga de Zapata, all subpopulations of G. c. caniceps are probably below 1,00o individuals. Any decline in the Zapata population below this threshold would result in this form qualifying as Vulnerable under C2a.

Therefore, we reaffirm that G. c. caniceps and G. c. leucometopius qualify as Vulnerable. In future assessments, G. c. leucometopius merits particular attention. Any indication that its range has fallen below $5,000 \mathrm{~km}^{2}$ would merit a full review of current sites and probably result in an uplisting to Endangered. Similarly, any indication that its population has fallen below 2,500 individuals would probably also result in a listing of Endangered.

There are currently draft proposals for amending these criteria (Species 31-32: 43-57, Hilton-Taylor 2000, C. Hilton-Taylor in litt. 2001). These changes are unlikely to result in a category change for either form, both remaining as Vulnerable.

\section{Conclusion}

Quail-doves, as a group, are reluctant flyers, and are unlikely to move between islands as disjunct as Hispaniola and Cuba. It can be presumed that the two populations have been isolated from one another for a considerable length of time, thus providing the span of time essential for evolution of basal taxa. According to available information, both taxa behave as authentic vicariant forms. Given this, we feel justified in the proposal to re-establish species status for the two forms of Grey-headed Quail-dove, providing much greater support, based on a larger series of specimens and a review of available ecological data, to the validity of Chapman's original proposal of separate species in the Dominican Republic and Cuba.

Avian taxonomy studies in the Greater Antilles are increasingly recognizing variation among closely related taxa at the species level, e.g. Greater Antillean Pewee Contopus caribaeus (three species according to Reynard et al. 1993), Palm Crow (two species proposed by Garrido et al. 1997a) and Stripe-headed Tanager Spindalis zena (four allospecies recognized by Garrido et al. 1997b). Most of these have subsequently gained acceptance by the AOU Check-list committee (AOU 1998, 2000).

Based on differences in coloration and pattern, position of the notch in the first primaries (second to fifth), statistically significant differences in tail length, and to some extent differences in habitat preferences, we recommend that the Cuban and Hispaniolan forms be considered separate species: Geotrygon caniceps Gundlach, 1852, endemic to Cuba, and Geotrygon leucometopius Chapman, 1917, endemic to the Dominican Republic. Appropriate vernacular names might be the Grey-headed (caniceps) and White-crowned (leucometopius) Quail-doves, which highlight the plumage features that separate them. Alternatively, they might be known as the Cuban and Hispaniolan Quail-doves, drawing attention to their endemicity, but this has disadvantages in that other quail-doves occur on both islands and caniceps is not the only Geotrygon unique to Cuba.

We consider that the evidence for our views is equal to, if not greater than, that presented by Peterson (1993) in support of species recognition for G. carrikeri, which has subsequently garnered widespread support. Like carrikeri, it is clear that leucometopius and caniceps would be treated as species under the Phylogen- 
etic Species Concept (McKitrick and Zink 1988), but hope that subsequent workers will test our theory using complete vocalization data and molecular DNA. For instance, conventional treatments of Antillean mimids, based on plumage and morphometrics, have recently been tested using molecular techniques, permitting confirmation of some previous relationships and drawing attention to the likelihood of previously unrealized systematic arrangements for other taxa (Hunt et al. 2001). We trust that these and other workers will turn their attention to Caribbean members of the genus Geotrygon in time.

\section{Acknowledgements}

We thank the curators, collection managers and technicians of the following institutions for their assistance: Louisiana State University Museum of Natural Science, Baton Rouge, Museum of Comparative Zoology at Harvard University, American Museum of Natural History, New York, Field Museum of Natural History, Chicago, Academy of Natural Sciences of Philadelphia, Natural History Museum, Tring and Museo Nacional de Historia Natural de Cuba, La Habana. Chris Milensky, at the National Museum of Natural History, Washington, kindly measured some specimens of nominate caniceps in his care. Richard Ranft, at the British Library National Sound Archive, prepared the final sonograms.

Allan Keith and George Wallace generously shared material currently in preparation, while David Wege facilitated access to the BirdLife International files concerning the two taxa, commented on an early version of the manuscript and all three, along with Andy Mitchell and Jim Wiley, remarked on drafts of this contribution. Seb Buckton (as editor) and Andy Mitchell (as one of the referees) greatly assisted in finalizing the text. Ariel Ruíz assisted with the preliminary statistical analysis and Phil Atkinson graciously undertook final analyses and presentation of the results. Thomas Stuart assisted DRC with the mapping of range sizes. Craig Hilton-Taylor provided information on revisions to the IUCN criteria.

OHG's travel to various museums and institutions in North America was supported by the RARE Center for Tropical Conservation, Fundación Luis Muñoz Marín, Victor L. González and a grant from the American Museum of Natural History. Kay and George Reynard generously provided hospitality during OHG's stay in Philadelphia, as did Van Remsen and Frederick Sheldon in Baton Rouge.

GMK is grateful to the following: Mike Flieg and Mark Elwonger for availing frequent travel opportunities to Cuba and the Dominican Republic in recent years, which permitted his studies of these quail-doves; Arturo Kirkconnell, who proved an admirable and always fun field companion, and showed much interest in our work, commenting on and providing additional information for the final text; Juan Mazar Barnett for further checking details of specimens held in the American Museum of Natural History, assistance with references and the Spanish summary, and confirming some of our ideas concerning these taxa; but reserves his greatest thanks to Daylén Chávez Bonachea and Barbará Chávez Bonachea for their hospitality in Pálpite, Ciénaga de Zapata (quail-dove watching area par excellence), during much of his fieldwork for this contribution. 
Appendix 1. List of localities and lending institutions for Grey-headed Quail-dove specimens examined.

All specimens were from one of the following institutions: Academy of Natural Sciences of Philadelphia (ANSP); American Museum of Natural History, New York (AMNH); Field Museum of Natural History, Chicago, Illinois (FMNH); Louisiana State University Museum of Natural Science, Baton Rouge (LSUMZ); Museo Nacional de Historia Natural de Cuba, La Habana (MNHNC); Museum of Comparative Zoology at Harvard University (MCZ); National Museum of Natural History, Washington (NHNM); Natural History Museum, Tring (NHM); and the Universidad de La Habana (UH). Not all specimens were included in the statistical analyses conducted by the authors. A small number of other collecting localities are listed in BirdLife International files, but the specimens were not examined by us.

Geotrygon c. caniceps (27 males, 17 females; 2 sex unknown, of which total three were young birds). Cuba: Bayate, Guantánamo (NMNH, 1 male, I female); Alchachofa Yateras, Guantánamo (NMNH, 1 male); San Cristóbal, locality untraced (NHM, sex unknown); Nagua, Sierra Maestra (AMNH, 4 males, 4 females); Cayo Yaguajusta (MCZ, 1 male); Remedios (MCZ, I male); Manzanillo (MNHNC, 1 female); Cajobobo (MNHNC, I male, I female); locality unknown, died in captivity in La Habana (NHM, sex unknown); Pico Turquino, Granma (AMNH, 2 males, 1 female); locality unknown (AMNH, I male); Ciénaga de Zapata (AMNH, 4 males, 2 females; MCZ, 5 males, 2 females; MNHNC, 1 female); Nagua (AMNH, 2 males, 2 females); unknown locality (UH, 4 males, 2 females).

Geotrygon c. leucometopius (17 males, 12 females; 1 sex unknown): Dominican Republic: Mt Tina, Azua (AMNH, 10 males, 5 females; ANSP, 1 male, 1 female; NHM, 2 males, 1 female); Túbano, Azua (AMNH, 2 males, 4 females, 1 sex unknown; FMNH, 1 male, 1 female; NHM, 1 male).

Appendix 2. List of localities for which attributable sight records are available.

Sources are Garrido et al. (in press.), Keith et al. (in press), BirdLife International files and personal observations by OHG, GMK and A. Kirkconnell.

Geotrygon c. caniceps. Cuba: Pinar del Río: Parque Nacional La Güira; Lomo del Caldero; Loma de Brujo; Sierra del Rosario (where known from Nortey, Loma del Salón and Loma del Taburete). Matanzas: Ciénaga de Zapata (where known from Santo Tomás, Peralta, Pálpite, El Roble, Mera, Soplillar, Molina, La Majagua, Los Sábalos, Punta Perdiz and Bermejas); Jovellanos; Punta de Maya. Villa Clara: Remedios. Camagüey: Sierra de Cubitas; also reported from Cayo Sabinal. Holguín: Cayo Saetía, (but unclear whether this involved a wild bird); Gibara; La Zoilita. Granma: Pico Cuba; Bayamo. Guantánamo: Yateras; Ojito de Agua, south-east of Moa.

Geotrygon c. leucometopius. Dominican Republic: Cordillera Central: Río Limpio; Constanza; El Convento; Jarabacoa; El Río; Paso Bajito de Jarabacoa; Casabito; Ébano Verde. Sierra de Neiba: unnamed locality near Haitian border; Loma Jacayo. Sierra de Baoruco: Loma del Toro, including El Aguacate; Polo; Loma del Cielo; near Barahona; Monteada Nueva de Barahona. 
Orlando H. Garrido, Guy M. Kirwan and David R. Capper

Appendix 3. Wing, tail, culmen and tarsus measurements (in $\mathrm{mm}$ ) for a total of 64 specimens of Geotrygon c. caniceps and G. c. leucometopius taken by OHG.

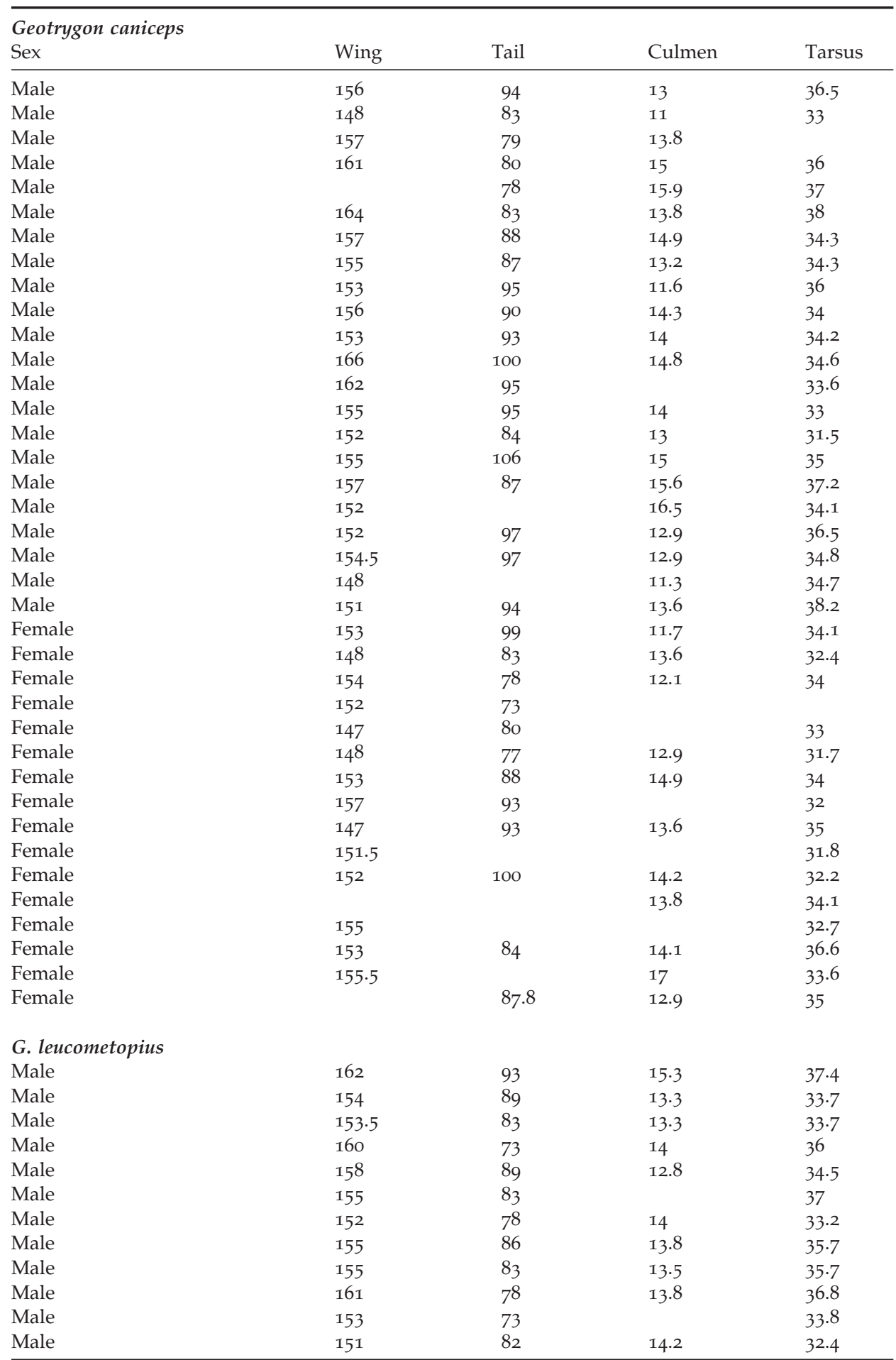


Appendix 3. Wing, tail, culmen and tarsus measurements (in $\mathrm{mm}$ ) for a total of 64 specimens of Geotrygon c. caniceps and G. c. leucometopius taken by OHG.

\begin{tabular}{lllll}
\hline $\begin{array}{l}\text { Geotrygon caniceps } \\
\text { Sex }\end{array}$ & Wing & Tail & Culmen & Tarsus \\
\hline Male & 147 & 76 & 17 & $34 \cdot 7$ \\
Female & 148 & 83 & 13.4 & 34.1 \\
Female & 150 & 80 & 13.5 & 33.1 \\
Female & 150 & 86 & 12.6 & 32.1 \\
Female & 153 & 91 & 14.3 & 33.6 \\
Female & 161 & 85 & & 36 \\
Female & 148 & 70 & 13.3 & 32.2 \\
Female & 145 & 74 & & 34.6 \\
Female & 149 & 95 & 12 & 32.4 \\
Female & 152 & 93 & 12.8 & 32 \\
Female & 152 & 95 & 11.7 & 34 \\
Female & 162 & 86 & 12.4 & $34 \cdot 7$ \\
Female & 154 & 77 & 14.2 & $33 \cdot 7$ \\
Female & 152 & & 32.2 \\
\hline
\end{tabular}

\section{References}

AOU (1998) Check-list of North American birds. Seventh edition. Washington, D.C.: American Ornithologists' Union.

AOU (2000) Forty-second supplement to the American Ornithologists' Union Check-list of North American birds. Auk 117: 847-858.

Baptista, L. F., Trail, P. W. and Horblit, H. M. (1997) Columbidae (Pigeons and doves). Pp. 6o-243 in J. del Hoyo, A. Elliott and J. Sargatal, J., eds. Handbook of the birds of the world, 4. Sandgrouse to cuckoos. Barcelona: Lynx Edicions.

Barbour, T. (1923) The birds of Cuba. Cambridge, MA: Memoirs of the Nuttall Ornithological Club.

BirdLife International (2000) Threatened birds of the world. Barcelona: Lynx Edicions and Cambridge, U.K.: BirdLife International.

Bond, J. (1928) The distribution and habits of the birds of the Republic of Haiti. Proc. Acad. Nat. Sci. Philadelphia 80: 483-521.

Bond, J. (1936) Birds of the West Indies. Philadelphia, PA: Academy of Natural Sciences Philadelphia.

Bond, J. (1956) Check-list of the birds of the West Indies. Philadelphia, PA: Academy of Natural Sciences Philadelphia.

Chapman, F. M. (1917) Description of new birds from Santo Domingo and remarks on others in the Brewster-Sanford Collection. Bull. Amer. Mus. Nat. Hist. 37: 327-334.

Collar, N. J., Gonzaga, L. P., Krabbe, N., Madroño Nieto, A., Parker T. A. and Wege, D. C. (1992) Threatened birds of the Americas: the ICBP/IUCN Red Data Book. Cambridge, U.K.: International Council for Bird Preservation.

Collar, N. J., Crosby, M. J. and Stattersfield, A. J. (1994) Birds to watch 2: the world list of threatened birds. Cambridge, U.K.: BirdLife International (Conserv. Series 4).

Garrido, O. H. and García Montaña, F. (1975) Catálogo de las aves de Cuba. La Habana: Acad. Cienc. Cuba.

Garrido, O. H. and Kirkconnell, A. (200o) Field guide to the birds of Cuba. Ithaca, NY: Comstock/Cornell University Press.

Garrido, O. H., Kirkconnell, A. and Wallace, G. E. (in press.) Catalogue of Cuban birds.

Garrido, O. H., Reynard, G. B. and Kirkconnell, A. (1997a) Is the Palm Crow, Corvus palmarum (Aves: Corvidae), a monotypic species? Orn. Neotrop. 8: 15-21. 
Garrido, O. H., Parkes, K. C., Reynard, G. B., Kirkconnell, A. and Sutton, R. (1997b) Taxonomy of the Stripe-headed Tanager, genus Spindalis (Aves: Thraupidae) of the West Indies. Wilson Bull. 109: 561-594.

Gibbs, D., Barnes, E. and Cox, J. (2001) Pigeons and doves: a guide to the pigeons and doves of the world. Robertsbridge: Pica Press.

Gundlach, J. (1852) Description of five new species of birds, and other ornithological notes on Cuban species. Boston J. Nat. Hist. 6(3): 313-319.

Gundlach, J. (1871) Neue Beiträge zur Ornithologie Cubas. J. Orn. 19: 265-295.

Gundlach, J. (1876) Contribución a la ornitología cubana. La Habana: Imprenta La Antilla.

Gundlach, J. (1893) Ornitología cubana. La Habana: Imprenta La Moderna.

Hardy, J. W., Reynard, G. B. and Coffey, B. B. (1989) Voices of New World pigeons and doves. Gainesville, FL: Bioacoustic Laboratory of Florida Museum of Natural History and ARA Records.

Hilton-Taylor, C. (compiler) (2000) 2000 IUCN Red List of threatened species. Gland, Switzerland and Cambridge, U.K.: IUCN.

Howell, S. N. G. (1998) Vocalisations and taxonomic status of the Purplish-backed Quaildove Geotrygon lawrencii. Cotinga 10: 20-22.

Howell, S. N. G. (1999) Tuxtlas Quail-dove: a response to Peterson. Cotinga 12: 4.

Hunt, J. S., Bermingham, E. and Ricklefs, R. E. (2001) Molecular systematics and biogeography of Antillean thrashers, tremblers and mockingbirds (Aves: Mimidae). Auk 118: $35-55$.

IUCN/SSC (1994) IUCN Red Data List categories. Gland, Switzerland: IUCN Species Survival Commission.

Keith, A. R., Wiley, J. W., Latta, S. C. and Ottenwalder, J. A. (in press) Birds of Hispaniola. BOU Check-list. Tring: British Ornithologists' Union.

Kirwan, G. M., Williams, R. S. R. and Bradshaw, C. G. (1999) Interesting avifaunal records from the Dominican Republic. Cotinga 11: 27-29.

McKitrick, M. C. and Zink, R. M. (1988) Species concepts in ornithology. Condor 90: 1-14.

Mitchell, A. and Wells, L. (1997) The threatened birds of Cuba project report. Cotinga 7: 69-71.

Pérez-Rivera, R. A. and Ruiz-Lebrón, C. R. (1997) Sobre el Patrón de Cortejo y el tamaño de la Camada de la Perdiz Azulona (Geotrygon caniceps leucometopius) de la República Dominicana. Caribbean J. Sci. 33: 281-283.

Peterson, A. T. (1993) Species status of Geotrygon carrikeri. Bull. Brit. Orn. Club 113: 166168.

Peterson, A. T. (1999) Tuxtlas Quail-dove: a response to Howell. Cotinga 12: 3-4.

Raffaele, H., Wiley, J., Garrido, O., Keith, A. and Raffaele, J. (1998) Birds of the West Indies. Princeton, NJ: Princeton University Press.

Reynard, G. B. (1981) Bird songs in the Dominican Republic. Ithaca, NY: Cornell Laboratory of Ornithology.

Reynard, G. B. and Garrido, O. H. (1988) Bird songs in Cuba. Ithaca, NY: Cornell Laboratory of Ornithology.

Reynard, G. B., Garrido, O. H. and Sutton, R. L. (1993) Taxonomic revision of the Greater Antillean Pewee. Wilson Bull. 105: 217-227.

Rodríguez, D. and Sánchez, B. (1993) Ecología de las palomas terrestres cubanas (géneros Geotrygon y Starnoenas). Poeyana 428: 1-20.

Stattersfield, A. J., Crosby, M. J., Long, A. J. and Wege, D. C. (1998) Endemic Bird Areas of the world: priorities for biodiversity conservation. Cambridge, U.K.: BirdLife International (Conserv. Series 7).

Stockton de Dod, A. (1978) Aves de la República Dominicana. Santo Domingo: Museo Nacional de Historia Natural. 
Stockton de Dod, A. (1981) Guía de campo para las aves de la República Dominicana. Santo Domingo: Museo Nacional de Historia Natural.

Svensson, L. (1992) Identification guide to European passerines. Fourth edition. Stockholm: privately published by the author.

Wells, L. and Mitchell, A. (1995) The threatened birds of Cuba project. March to July 1995. Unpublished report to BirdLife International.

Wetmore, A. (1920) Five new species of birds from cave deposits in Porto Rico. Proc. Biol. Soc. Wash. 33: 77-81.

Wetmore, A. (1922) Bird remains from the caves of Porto Rico. Bull. Amer. Mus. Nat. Hist. 46: $297-333$.

Wetmore, A. (1927) The birds of Porto Rico and the Virgin Islands. Ann. New York Acad. Sci. 9: 245-406.

Wetmore, A. and Swales, B. H. (1931) The birds of Haiti and the Dominican Republic. U.S. Nat. Mus. Bull. 155.

ORLANDO H. GARRIDO

Museo Nacional de Historia Natural de Cuba, Obispo 61, Plaza de Armas, La Habana, Cuba.

GUY M. KIRWAN ${ }^{1}$

74 Waddington Street, Norwich, Norfolk NR2 4JS, U.K.

DAVID R. CAPPER

1029A Garratt Lane, Tooting, London SW17, U.K.

${ }^{1}$ Author for correspondence.

Received 4 June 2001; revision accepted 7 January 2002 